PERM JOURNAL OF PETROLEUM AND MINING ENGINEERING ВЕСТНИК ПНИПУ. ГЕОЛОГИЯ. НЕФТЕТАЗОВОЕ И ГОРНОЕ ДЕЛО

ISSN 2224-9923

Volume/Tom 19 №2 2019

http://vestnik pstu.ru/geo/

UDC 622.276.023.43

Article / Статья

(c) PNRPU / ПНИПУ, 2019

\title{
EXPRESS PREDICTING MOVEMENT OF DISPLACEMENT FRONT TO HIGH VISCOSITY OIL RESERVOIRS
}

\section{Irina S. Poplygina, M. Wiercigroch ${ }^{1}$}

PermNIPIneft branch of LUKOIL-Engineering LLC in Perm (29 Sovetskoy Armii st., Perm, 614000, Russian Federation)

${ }^{1}$ University of Aberdeen (Centre for Applied Dynamics Research, King's College, AB24 3UE, Aberdeen,

United Kingdom of Great Britain and Northern Ireland)

\section{ЭКСПРЕСС-ПРОГНОЗИРОВАНИЕ ПЕРЕМЕЩЕНИЯ ФРОНТА ВЫТЕСНЕНИЯ НА ЗАЛЕЖИ С ВЫСОКОВЯЗКОЙ НЕФТЬЮ}

\section{И.С. Поплыгина, М. Уирсигроч${ }^{1}$}

Филиал ООО «ЛУКОЙЛ-Инжиниринг» «ПермНИПИнефть» в г. Перми (614000, Россия, г. Пермь, ул. Советской Армии, 29) ${ }^{1}$ Абердинский университет (Шотландия, Соединенное Королевство Великобритании и Северной Ирландии, Местон Билдинг, Кингс Колледж, Абердин АВ24, 3UE)

Received / Получена: 02.04.2019. Accepted / Принята: 01.06.2019. Published / Опубликована: 28.06.2019

Key words:

oil reservoir, well, oil viscosity, permeability, water flooding, water shutoff, forecasting, multidimensional model.

\section{Ключевые слова:}

залежь нефти, скважина, вязкость нефти, проницаемость, обводненность, водоизоляция, прогнозирование, многомерная модель.
Practically in all oil fields water injection is performed to maintain formation pressure. At bottom holes of injection wells pressures are created which significantly exceed formation pressure. In case of significant layer to layer heterogeneity water from injection wells will start flowing through low filtration resistance channels to productive wells. In the most intense way movement of injection water from injection well to productive well manifests itself in high viscosity oil reservoirs. In case of productive well water flooding works on water shutoff and equalizing input profiles are performed. To evaluate time of water breakthrough from productive well to injection well using software suite TempestMore a series of mathematic experiments was made to forecast displacement front movement in formation with different formation oil viscosities, reservoir permeability, bottom hole pressures in injection and productive well. Information on fluid properties and relative permeability at fields of Nozhovskaya group (Perm territory) was used. According to results of generalization of simulation data an equation for evaluation of time of displacement front movement in reservoir is obtained. Analyzing calculation results, it is possible to conclude that time of displacement front movement for certain distance is influenced by mobility coefficient according to exponential dependency. In reservoirs with mobility over $2 \mu \mathrm{m}^{2} / \mathrm{Pa}^{*} \mathrm{sec}$ water-oil front moves with velocity of around $1 \mathrm{~m} /$ day. Comparison of forecasted values of production wells water flooding time for high viscosity oil reservoir obtained by hydrodynamic simulation and equation developed demonstrates high enough results reproducibility. Usage of the equation will permit to plan in advance measures on well water shutoff and equalizing input profiles.

Irina S. Poplygina (Author ID in Scopus: 55531866900) - Engineer (tel.: +007 909727 11 57, e-mail: davydova_irina@bk.ru). The contact person for correspondence. Marian Wiercigroch (Author ID in Scopus: 56229012200) - Professor (tel.:+4401 2242724 97, e-mail: m.wiercigroch@abdn.ac.uk).

Поплыгина Ирина Сергеевна - инженер (тел.: +007 90972711 57, e-mail: davydova_irina@bk.ru). Контактное лицо для переписки.

Уирсигроч Мариан - профессор (тел.:+4401 2242724 97, e-mail: m.wiercigroch@ab̄̄n.ac.uk). 


\section{Introduction}

Development of oil fields is accompanied with water injection to maintain formation pressure, leading to increase of reservoir oil recovery and increased water cut in productive wells. Injection water moves in reservoir from injection to productive wells. If there are sublayers with low filtration resistance in reservoir, speed of water movement increases. Along with increase of reservoir layer to layer heterogeneity and oil viscosity probability of premature water breakthrough to productive wells increases [1]. Together with geological parameters $[2,3,4]$, well flooding is influenced by development systems and well operation process patterns [5-9]. Along with increase of well water flooding during oil field development current production decreases, oil recovery coefficient decreases, inorganic salts sedimentation intensifies and oil production cost increases [10]. main reasons for well water flooding are coning and advanced movement of water front along highly permeable sublayers [11-16]. In Perm territory water movement along most permeable sublayers is one of main sources of productive wells water flooding. To prevent premature well water flooding and to increase formation coverage they perform injection of polymers, cyclic water flooding, and other processes are used, meanwhile greatest process effectiveness is demonstrated by usage of gel-forming processes [17-42].

\section{Object of study}

Large group of reservoirs with highly viscous oil in Perm territory is associated with fields of Nozhovskaya group. Viscosity of formation oil in carbonate objects of Nozhovskaya fields group changes from 7,9 to $87,08 \mathrm{mPa} \cdot \mathrm{sec}$, permeability of productive objects according to core data $0,060-0,646 \mu \mathrm{m}^{2}$, compartmentalization $-1,0-9,6$. In the greater part of carbonate objects in the group significant advantage of water flooding over production of recoverable reserves. On a number of objects well production water flooding exceeds production of recoverable reserves by 1,5 times and more. Main reason for production water flooding of wells associated with carbonate reservoir objects in Nozhovskaya fields group is water flooding through more permeable part (separate layers) of laminary non-uniform reservoir $(56,3 \%)$. Also to most common water flooding reasons pertain edge water breakthrough (18.8\%) and coning (12.5\%). For more effective implementation of processes on equalizing injection wells input profiles and water shutoff in productive wells it is necessary to evaluate time of their appropriate application. A task of practical importance is determination of production wells water flooding time and time of displacement front movement in reservoir parts having different permeability. It is possible to evaluate time of displacement front passing over distance from injection to productive well using geological hydrodynamic displacement method. Availability of multidimensional statistical models will permit to substantially simplify and improve promptness of front movement time evaluation.

\section{Simulation of water front movement}

In work [43, 44] dependencies of well water flooding on production of recoverable resources for oil having different viscosity are given. These dependencies permit to forecast amount of water flooding at different stages of reservoir development. Oil recovery coefficients and rates of reserves recovery depend on reservoir permeability, formation oil dynamic viscosity, levels of production and compensation of recovery by fluid injection [45]. Dependencies described in the literature permit to obtain integral values of water flooding for reservoirs in whole.

A model is created in software suite TempestMore of uniform reservoir compartment with productive and injection wells. Calculations of displacement front movement from productive to injection well depending on formation oil properties, reservoir permeability and bottom hole pressures of productive and injection wells are performed. Displacement front movement border was considered to be increase of water saturation of model grid blocks. Average reservoir permeability, relative permeability and fluid parameters values were set similar to actual fields of Nozhovskaya group.

Analyzing calculation results we may conclude that time of displacement front movement over certain distance is influenced by mobility coefficient according to exponential dependency (ratio of permeability coefficient and formation oil dynamic viscosity) (fig. 1). In sublayers with mobility coefficient less than $2 \mu \mathrm{m}^{2} / \mathrm{Pa} \cdot \mathrm{sec}$ time of displacement front movement from injection well to 
productive well corresponds to times of oil recoverable resources production, and premature water flooding of productive wells is unlikely. In reservoirs with mobility over $2 \mu \mathrm{m}^{2} / \mathrm{Pa} \cdot \mathrm{sec}$ water-oil front moves with velocity around $1 \mathrm{~m} /$ day. Especially intensely water-oil front moves in formations with mobility coefficients over $5 \mu \mathrm{m}^{2} / \mathrm{Pa} \cdot \mathrm{sec}$, and time of displacement front movement between wells may not exceed one year. It is necessary to monitor in productive objects water-oil front movement in sublayers with high mobility coefficient and plan measures on equalizing injection wells input profiles and water shutoff in productive wells [46].

In Statistica program regressive analysis of main model parameters influence on times of water-oil front movement in formations was performed. The priority for analysis is area in reservoirs with mobility over $2 \mu \mathrm{m}^{2} / \mathrm{Pa} \cdot \mathrm{sec}$.

An equation for evaluation of time of displacement front movement (years) for distance $X$ from injection well is obtained:

- for objects with mobility coefficients 2$5 \mu \mathrm{m}^{2} / \mathrm{Pa} \cdot \mathrm{sec}$ :

$T=0,14 X-0,96 k / \mu+1,82\left(P_{\mathrm{i}}-P_{\mathrm{p}}\right) / P_{\mathrm{f}}-1,02 ;$

- для объектов с коэффициентами подвижности более $5 \mu \mathrm{m}^{2} / \mathrm{Pa} \cdot \mathrm{sec}$ :

$T=0,018 X-0,18 k / \mu+1,14\left(P_{\mathrm{i}}-P_{\mathrm{p}}\right) / P_{\mathrm{f}}+2,8$,

where $X$ - distance from injection well, $\mathrm{m}$; $k$ - reservoir permeability, $10^{-3} \cdot \mu \mathrm{m}^{2} ; \mu$ - formation pressure dynamic viscosity, $\mathrm{mPa} \cdot \mathrm{sec} ; P_{\mathrm{i}}, P_{\mathrm{p}}-$ bottom hole pressures in injection and productive wells correspondingly, $\mathrm{MPa} ; P_{\mathrm{f}}-$ formation pressure, MPa.

For dependency (1) it is necessary to use following limits on source parameters:

$\mathrm{X}-50-500 \mathrm{~m}$;

$k / \mu-2-30 \mu \mathrm{m}^{2} / \mathrm{Pa} \cdot \mathrm{sec}$;

$\left(P_{\mathrm{i}}-P_{\mathrm{p}}\right) / P_{\mathrm{f}}-0,625-1,06$ unit fraction.

In one of divisions of Berezovskoe oil field water flooding of productive well 727 by water injected into injection well 779 is observed. In injection well 779 with input profile of $30 \mathrm{~m}^{3} /$ day about $80 \%$ of injected water goes into upper perforation interval and moves to well 727 (fig. 2).

Study of time of water flooding in well 727 depending on time after activation of injection well 779 was performed (fig. 3). Water flooding of well 727 began to rise step by step and reached
$85 \%$ in 6 years. According to results of processsing well testing average mobility coefficient in well drainage areas was $16,9 \mu \mathrm{m}^{2} / \mathrm{Pa} \cdot \mathrm{sec}$. Bottom hole pressure in productive and injection wells was 11 and $23 \mathrm{MPa}$ respectively. Formation pressure - $16 \mathrm{MPa}$. Time of water-oil front movement from injection to productive well during forecasting using dependency (2) will be 7 years, which corresponds to well water flooding in fig. 3.

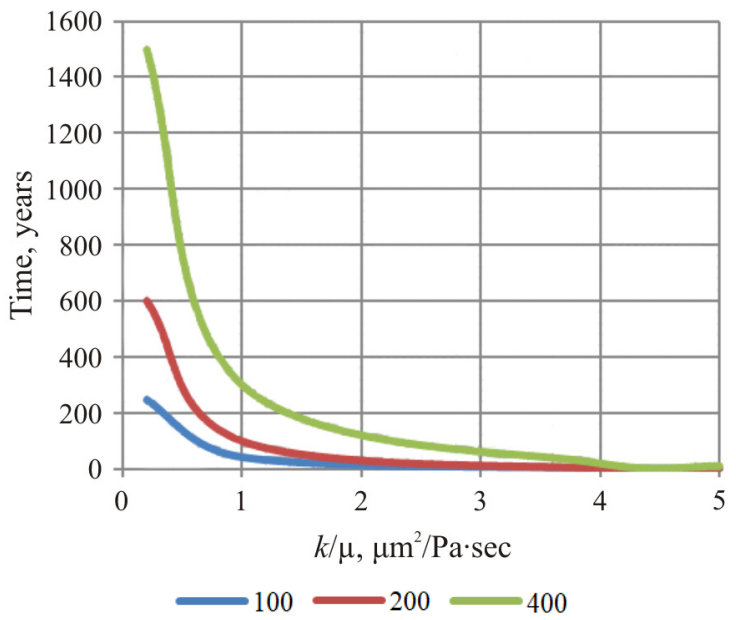

Fig. 1. Dependency of time of water front movement over distance 100/200/400 $\mathrm{m}$ from injection well in relation to mobility coefficient

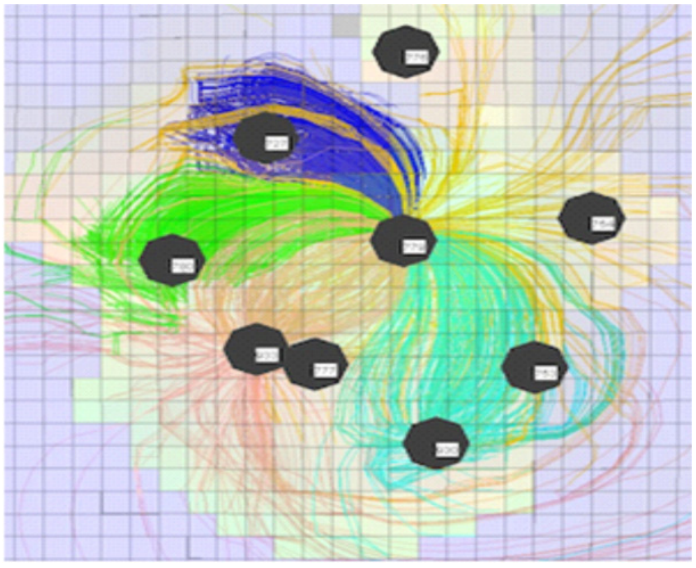

Fig. 2. Directions of filtration flows in oil reservoir compartment

Before expected well water flooding through highly permeable sublayer it is necessary to plan measures on equalizing input profile of injection well. Timely usage of flow diverting technologies will permit to increase effectiveness of reservoir management and will lead to increase oil recovery coefficient. 


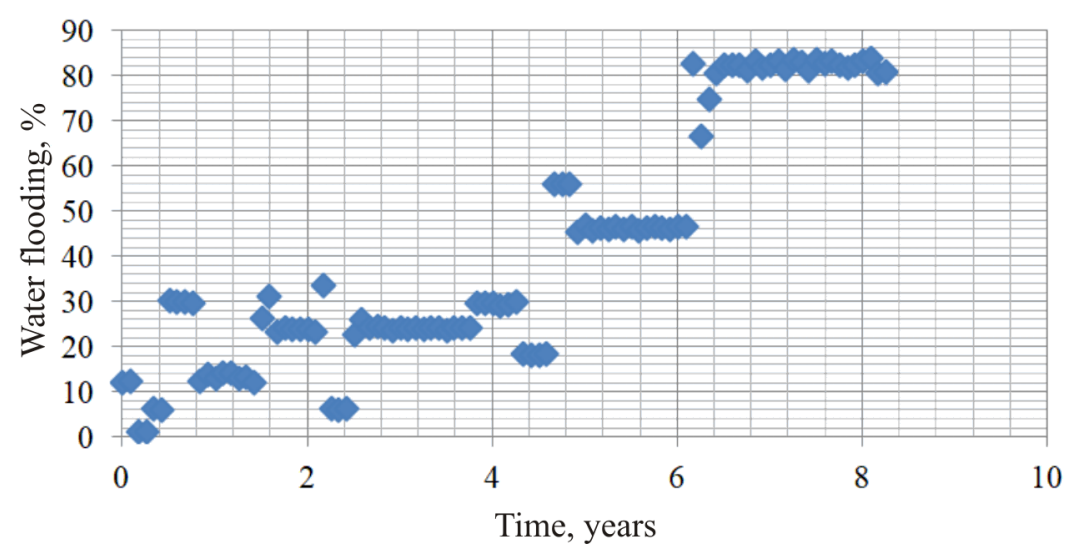

Fig. 3. Dynamics of water flooding well 727 after beginning water injecting to well 779

\section{Conclusions}

At present substantial part of productive objects contains hard to recover oil reserves. Such objects are characterized by significant layer to layer and zonal heterogeneity, high viscosity of oil and other complicating factors. For effective implementation of input profile adjustment and well water shutoff processes it is necessary to forecast time of arrival of water being injected into formation to productive wells.
The work proposes dependencies for evaluation of time of water front movement in formation. Special attention should be given to sublayers with mobility coefficient value exceeding $2 \mu \mathrm{m}^{2} / \mathrm{Pa} \cdot \mathrm{sec}$, as in these substantial speeds of water-oil front are obtained.

\section{Acknowledgment}

The study sponsored by Perm Territory Administration within scientific project № S-26/786 of 21.12.2017.

\section{References}

1. Kudryashova D.A. Use of probabilistic and statistical methods for determination of the sources of water flow in candidate wells for water shut-off works (on example of the Visean reservoir of the Perm region field). Perm Journal of Petroleum and Mining Engineering, 2018, vol.17, no.1, pp.26-36. DOI: $10.15593 / 2224-9923 / 2018.1 .3$

2. Rakintseva I.A. Geologicheskie prichiny prezhdevremennogo obvodneniia skvazhin Polaznenskogo mestorozhdeniia [Geological causes of premature well flooding of the Polazna field]. Geology, Geophysics and Development of Oil and Gas Fields, 2007, no.9, pp.21-23.

3. Sarvarov A.R. Analiz prichin prezhdevremennogo obvodneniia produktsii skvazhin, ekspluatiruiushchikh plasty gruppy AV Samotlorskogo mestorozhdeniia [Analysis of the causes of premature flooding of wells producing reservoirs of the AV group of the Samotlor field]. Oilfield engineering, 2009, no.1, pp.21-25.

4. Kandakova T.V., Startsev I.S. Analiz vliianiia geologicheskogo stroeniia na obvodnennost produktsii turneiskoi zalezhi Etyshskogo mestorozhdeniia [Analysis of the influence of the geological structure on the water content of the Tournaisian reservoir of the Etyshskoye field]. Problemy razrabotki mestorozhdenii uglevodorodnykh $i$ rudnykh poleznykh iskopaemykh, 2017, no.1, pp.153-155.

5. Osmanov B.A., Ozturk S.R., Salavatova R.Sh., Mustafaev K.I. Issledovanie faktorov, vliiaiushchikh na obvodnenie dobyvaiushchikh skvazhin [Factors affecting the development of irrigation production wells]. Oilfield engineering, 2014, no.5, pp.52-54.

6. Nekrasov A.S., Rakintseva L.N. Osnovnye prichiny obvodneniia ekspluatatsionnykh skvazhin mestorozhdenii Srednego Priobia (na primere Vostochno-Pridorozhnogo mestorozhdeniia) [The main reasons for the flooding of production wells of the Middle Priobye fields (on example of the EastPridorozhnoye field)]. Izvestiia vysshikh uchebnykh zavedenii. Neft i gaz, 2004, no.5, pp.87-92.

7. Gadzhiev G.K., Aliev E.M., Bagirov Sh.A. Vliianie profilia naklonno napravlennykh skvazhin na obvodnennost ikh produktsii [Influence of deviated wells profiles on water-flooding of their product]. Oilfield engineering, 2014, no.9, pp.51-54.

8. Fattakhov I.G. Sistematizatsiia prichin proryva vody $\mathrm{v}$ dobyvaiushchie skvazhiny [Systematization 
of the causes of water breakthrough in production wells]. Oilfield engineering, 2011, no.12, pp.17-19.

9. Kochneva O.E., Limonova K.N. Evaluation water cutting wells and product Yasnopolyanskaya superhorizon Moskudinskogo deposit. Perm Journal of Petroleum and Mining Engineering, 2014, vol.13, no.10, pp.66-72. DOI: 10.15593/2224-9923/2014.10.6.

10. Nasyrov V.A., Shliapnikov Iu.V., Nasyrov A.M. Obvodnennost produktsii skvazhin i vliianie ee na oslozhniaiushchie faktory $\mathrm{v}$ dobyche nefti [Water production of wells and its influence on complicating factors in oil production]. Ekspozitsiia Neft Gaz, 2011, no.2 (14), pp.14-17.

11. Lysenkov E.A., Anosov E.V. Preduprezhdenie rannego obvodneniia skvazhin [Prevention of early wells flooding]. Oil industry, 2004, no.1, pp.61-63.

12. Sukubo I., Iyow O., Balogun O., Jude-Ofia I., Onunekwu, C. Water diagnostic analysis: The gains of integration. Society of Petroleum Engineers - Nigeria Annual International Conference and Exhibition, 2017, pp.1622-1638. DOI: 10.2118/189064-MS

13. Pirozhkov M. Introduction of innovative set for real-time process control used for watercut prediction. Society of Petroleum Engineers - SPE Russian Petroleum Technology Conference. Moscow, 2015. DOI: $10.2118 / 177968-R U$

14. Ogezi O., Strobel J., Egbuniwe D., Leonhardt B. Advanced data-driven performance analysis for mature waterfloods. Operational aspects of a biopolymer flood in a Mature Oilfield. SPE - DOE Improved Oil Recovery Symposium Proceedings, 2014, no.3, pp. 1735-1751. DOI: 10.2118/174872-MS

15. Qu Y.G., Liu Y.T., Ding Z.P. Studies on the factors affecting watercut of a single well in a complicated fault-block reservoir by applying the numerical simulation method. Petroleum Science and Technology, no.30(23), pp.2478-2487. DOI: 10.1080/10916466.2010.516297

16. Saadatpoor E., Karami H., Al-Ajmi M.F. A new method for dynamic calculation of pattern allocation factors in waterflood monitoring. Proceedings SPE Symposium on Improved Oil Recovery, 2012, no.1, pp.402-412. DOI: 10.2118/153802-MS

17. Mordvinov V.A., Poplygin V.V., Poplygina I.S. Methods of polymer flooding of high-viscosity oil pools. Perm Journal of Petroleum and Mining Engineering, 2015, vol.14, no.14, pp.39-51. DOI: $10.15593 / 2224-9923 / 2015.14 .5$

18. Poplygin V.V., Wiercigroch M. Evaluation of the wave effect effectiveness in carbonate reservoirs with high viscosity oil. Perm Journal of Petroleum and Mining Engineering, 2018, vol.18, no.2, pp.149-156. DOI: $10.15593 / 2224-9923 / 2018.4 .5$

19. Gladkikh E.A., Khizhniak G.P. Rezultaty issledovanii vodoizoliatsionnogo sostava na kernovoi modeli sloisto-neodnorodnogo plasta [Results of research of waterproofing composition on a core model of a layered heterogeneous formation]. Oil industry, 2017, no.11, pp.118-121. DOI: 10.24887/0028-2448-2017-11-118-121

20. Kolganov V.I., Fomina A.A., Demin S.V., Morozova A.Iu. O "kovarnom" zakone obvodneniia i nefteotdachi karbonatnykh treshchinno-porovykh kollektorov [About the "guileful" law of flooding and oil recovery of carbonate fractured porous reservoirs]. Oil industry, 2008, no.1, pp.66-70.

21. Kazakov A.A., Solovev I.G. Dinamicheskaia model obrazovaniia konusa obvodneniia vertikalnoi neftianoi skvazhiny [Dynamic model of formation of water cone of the vertical oil well]. Vestnik Tiumenskogo gosudarstvennogo universiteta. Fizikomatematicheskoe modelirovanie. Neft, gaz, energetika, 2011, no.7, pp.52-58.

22. Azamatov M.A., Shorokhov A.N. Vnedrenie metoda operativnoi diagnostiki istochnikov obvodneniia neftianykh dobyvaiushchikh skvazhin [Application of the method for operative determination of production wells watering source]. Oil industry, 2011, no.12, pp.63-65.

23. Shuvalov S.A., Vinokurov V.A., Khlebnikov V.N. Primenenie polimernykh reagentov dlia uvelicheniia nefteotdachi plasta i vodoizoliatsii [Using polymeric agents for eor and waterproofing]. Trudy Rossiiskogo gosudarstvennogo universiteta nefti $i$ gaza im. I.M. Gubkina, 2013, no.4 (273), pp.98-107.

24. Izbrekht a.v., Panikarovskii E.V., Kustyshev A.V. Metody i vodoizoliruiushchie kompozitsii dlia provedeniia remontno-izoliatsionnykh rabot $\mathrm{v}$ neftianykh i gazovykh skvazhinakh [Methods and water-isolating compositions used for performing repair-isolation work in oil and gas wells]. Stroitelstvo neftianykh i gazovykh skvazhin na sushe i na more, 2013, no.6, pp.31-34.

25. Raspopov A.V., Kazantsev A.S., Andreev D.V., Averina I.V., Sidorenko D.D., Glazyrin S.N. Opyt i perspektivy primeneniia tekhnologii ogranicheniia vodopritoka na mestorozhdeniiakh Permskogo kraia [Experience and prospects of application of water inflow limitation in the firlds of Perm region]. Geologiia, geofizika $i$ razrabotka neftianykh $i$ gazovykh mestorozhdenii, 2016, no.9, pp.41-45.

26. Kulikov A.N., Silin M.A., Magadova L.A., Eliseev D.Iu. Optimizatsiia posledovatelnosti 
primeneniia tekhnologii ogranicheniia vodopritokov i povysheniia nefteotdachi plasta $\mathrm{v}$ khode razrabotki zalezhei nefti [Optimization of the sequence of application of technologies to limit water inflow and enhance oil recovery during the development of oil deposits]. Territoriia Neftegaz, 2013, no.4, pp.64-69.

27. Kulikov A.N. Metodika vybora skvazhin dlia provedeniia rabot po ogranicheniiu vodopritokov i vosstanovleniiu dobyvaiushchego fonda [Methodology of well selection for carrying out work aimed at water inflow limitation and producing wells renewal]. Oilfield engineering, 2012, no.7, pp.19-23.

28. Kunakova A.M., Duriagin V.N., Strizhnev K.V., Mardashov D.V., Duriagina A.M. Neorganicheskaia geleobrazuiushchaia kompozitsiia dlia ogranicheniia vodopritoka $\mathrm{v}$ karbonatnykh treshchinovato-porovykh kollektorakh [Inorganic gel-forming composition for water shut-off in carbonate reservoir of fracturedporous type]. Oil industry, 2015, no.11, pp.114-116.

29. Batrashkin V.P. Algoritm vybora skvazhin dlia primeneniia kombinirovannogo vozdeistviia so storony nagnetatelnoi i dobyvaiushchei skvazhin na neodnorodnye neftenasyshchennye kollektory [The algorithm for selecting wells for the application of the combined effects of the injection and production wells on heterogeneous oil-saturated reservoirs]. Avtomatizatsiia, telemekhanizatsiia $i$ sviaz $v$ neftianoi promyshlennosti, 2007, no.9, pp.33-39.

30. Sulima S.A., Sonich V.P., Misharin V.A., Isachenko V.M., Bulatov R.A., Samsonenko D.V. Potokootkloniaiushchie tekhnologii - osnovnoi metod regulirovaniia razrabotki vysokozavodnennykh zalezhei [Baffling technologies - main method to control development of highly watered deposits]. Oil industry, 2004, no.2, pp.44-50.

31. Mamchistova E.I., Zviagin E.M., Guso M., Valiev O.V., Kovalenko E.F., Tapilin V.N. Meropriiatiia po ogranicheniiu pritoka plastovykh vod i povysheniiu produktivnosti skvazhin [Measures to limit the inflow of reservoir water and increase well productivity]. Nauchnyi forum. Sibir, 2015, no.1, pp.53-55.

32. Keller Iu.A. Razrabotka iskusstvennykh neironnykh setei dlia predskazaniia tekhnologicheskoi effektivnosti ot vyravnivaniia profilia priemistosti [Design of artificial neural networks for predicting the technological efficiency of improving water injection profile]. Izvestiia Tomskogo politekhnicheskogo universiteta, 2014, vol.325, no.5, pp.60-65.

33. Sagyndikov M., Mukhambetov B., Orynbasar Y., Nurbulatov A., Aidarbayev S. Evaluation of polymer flooding efficiency at brownfield development stage of giant Kalamkas oilfield, western Kazakhstan. SPE Annual Caspian Technical Conference and Exhibition. Astana 2018. DOI: 10.2118/192555-MS

34. Liu Y., Wu H., Hou J., Wei C., Ren W. An injection/production rate allocation method applied for polymer-surfactant flooding. Journal of Engineering Research, 5(2), pp.250-267

35. Al Sofi A.M., Wang J., Al Shuaibi A.A., Al Ghamdi F.A., Kaidar Z.F. Systematic development and laboratory evaluation of secondary polymer augmentation for a slightly viscous Arabian heavy reservoir. SPE Middle East Oil and Gas Show and Conference, MEOS, Proceedings, 2017, pp.2757-2764. DOI: 10.2118/183793-MS

36. Maksimovskiy I.V., Akimov A.G., Yamaletdinov A.F., Zhilina M.A. Waterflooding optimization in case of auto-frac naturally fractured reservoir. Society of Petroleum Engineers SPE Russian Petroleum Technology Conference and Exhibition, 2016, pp.2723-2738. DOI: 10.2118/181991-MS

37. Jin J., Choe J. Positioning of an injection well by combining watercut matching and adjoint method. Proceedings of IAMG 2015 - 17th Annual Conference of the International Association for Mathematical Geosciences, 2015, pp.351-356.

38. Guo H.-Z., Li D.-M. Flagship application in high water cut horizontal well. Xinan Shiyou Daxue Xuebao. Journal of Southwest Petroleum University, 2009, no.31(1), pp. 107-110. DOI: 10.3863/j.issn.16745086.2009.01.026

39. Pu H., Yin D. Study of polymer flooding in class III reservoir and pilot test. Proceedings - SPE Symposium on Improved Oil Recovery, 2008, no.1, pp.10-25. DOI: 10.2118/109546-MS

40. Stirpe M.T., Guzman J., Manrique E., Alvarado V. Cyclic water injection simulations for evaluations of its potential in lagocinco field. Proceedings - SPE Symposium on Improved Oil Recovery. Tulsa, 2004. DOI: 10.2118/89378-MS

41. Thyne G. Evaluation of the effect of low salinity waterflooding for 26 fields in Wyoming. Proceedings SPE Annual Technical Conference and Exhibition, 2011, no.5, pp.4390-4407. DOI: 10.2118/147410-MS

42. Wu X.-C., Wang H.-G., Li F.-X., Zeng Q.-Q. EOR mechanisms and field practice of flowing gel profiling/flooding. Oilfield Chemistry, 2009, 26(1), pp. 79-83.

43. Galkin S.V., Iliushin P.Iu. Prognoz dinamiki obvodnennosti skvazhin $\mathrm{V}$ razlichnykh geologotekhnologicheskikh usloviiakh razrabotki neftianykh mestorozhdenii [Forecast of wells water cut in 
different geological and technological conditions of oil field development]. Oil industry, 2011, no.10, pp.22-24.

44. Ilyushin P.Y., Galkin S.V. Forecast water cut production wells perm with the a-statistical methods. Perm Journal of Petroleum and Mining Engineering, 2011, vol.10, no.1, pp.76-84.

45. Nazarova L.N. Obosnovanie koeffitsienta izvlecheniia nefti $\mathrm{v}$ zavisimosti ot kompleksa geologo-fizicheskikh parametrov plastov i nasyshchaiushchikh ikh fliuidov [Substantiation of the oil recovery factor depending on the complex of geological and physical parameters of the formations and the fluids that saturate them]. Doctor's degree dissertation. Moscow, 2015.

46. Poplygina I.S. Opportunities of improved development of high-viscosity oil pool in Perm kray. Perm Journal of Petroleum and Mining Engineering, 2014, vol.13, no.11, pp.57-66. DOI: $10.15593 / 2224-9923 / 2014.11 .6$

\section{Библиографический список}

1. Кудряшова Д.А. Использование вероятностно-статистических методов для определения источников обводнения скважин-кандидатов для водоизоляционных работ (на примере визейского объекта месторождения Пермского края) // Вестник Пермского национального исследовательского политехнического университета. Геология. Нефтегазовое и горное дело. - 2018. - Т. 17, № 1. - С. 26-36. DOI: $10.15593 / 2224-9923 / 2018.1 .3$

2. Ракинцева И.А. Геологические причины преждевременного обводнения скважин Полазненского месторождения // Геология, геофизика и разработка нефтяных и газовых месторождений. 2007. - № 9. - C. 21-23.

3. Сарваров А.Р. Анализ причин преждевременного обводнения продукции скважин, эксплуатирующих пласты группы $\mathrm{AB}$ Самотлорского месторождения // Нефтепромысловое дело. - 2009. № 1. - C. 21-25.

4. Кандакова Т.В., Старцев И.С. Анализ влияния геологического строения на обводненность продукции турнейской залежи Этышского месторождения // Проблемы разработки месторождений углеводородных и рудных полезных ископаемых. - 2017. - № 1. - С. 153-155.

5. Исследование факторов, влияющих на обводнение добывающих скважин / Б.А. Османов, С.Р. Озтурк, Р.Ш. Салаватова, К.И. Мустафаев // Нефтепромысловое дело. - 2014. - № 5. - С. 52-54.

6. Некрасов А.С., Ракинцева Л.Н. Основные причины обводнения эксплуатационных скважин месторождений Среднего Приобья (на примере Восточно-Придорожного месторождения) // Известия высших учебных заведений. Нефть и газ. 2004. - № 5. - C. 87-92.

7. Гаджиев Г.К., Алиев Е.М., Багиров Ш.А. Влияние профиля наклонно направленных скважин на обводненность их продукции // Нефтепромысловое дело. - 2014. - № 9. - С. 51-54.

8. Фаттахов И.Г. Систематизация причин прорыва воды в добывающие скважины // Нефтепромысловое дело. - 2011. - № 12. - С. 17-19.

9. Кочнева О.Е., Лимонова К.Н. Оценка обводненности скважин и продукции яснополянской залежи Москудьинского месторождения // Вестник Пермского национального исследовательского политехнического университета. Геология. Нефтегазовое и горное дело. - 2014. - Т. 13, № 10. - С. 66-72. DOI: $10.15593 / 2224-9923 / 2014.10 .6$

10. Насыров В.А., Шляпников Ю.В., Насыров A.M. Обводненность продукции скважин и влияние ее на осложняющие факторы в добыче нефти // Экспозиция Нефть Газ. - 2011. № 2 (14). - C. 14-17.

11. Лысенков Е.А., Аносов Э.В. Предупреждение раннего обводнения скважин // Нефтяное хозяйство. - 2004. - № 1. - С. 61-63.

12. Water diagnostic analysis: The gains of integration / I. Sukubo, O. Iyowu, O. Balogun, I. Jude-Ofia, C. Onunekwu // Society of Petroleum Engineers - Nigeria Annual International Conference and Exhibition. - 2017. - P. 1622-1638. DOI: $10.2118 / 189064-M S$

13. Pirozhkov M. Introduction of innovative set for real-time process control used for watercut prediction // Society of Petroleum Engineers - SPE Russian Petroleum Technology Conference. - Moscow, 2015. DOI: $10.2118 / 177968-R U$

14. Advanced data-driven performance analysis for mature waterfloods / O. Ogezi, J. Strobel, D. Egbuniwe, B. Leonhardt // Operational aspects of a biopolymer flood in a Mature Oilfield // SPE - DOE Improved Oil Recovery Symposium Proceedings. 2014. - № 3. - P. 1735-1751. DOI: 10.2118/174872-MS 
15. Qu Y.G., Liu Y.T., Ding Z.P. Studies on the factors affecting watercut of a single well in a complicated fault-block reservoir by applying the numerical simulation method // Petroleum Science and Technology. - № 30 (23). - P. 2478-2487. DOI: $10.1080 / 10916466.2010 .516297$

16. Saadatpoor E., Karami H., Al-Ajmi M.F. A new method for dynamic calculation of pattern allocation factors in waterflood monitoring // Proceedings SPE Symposium on Improved Oil Recovery. - 2012. - № 1. - P. 402-412. DOI: $10.2118 / 153802-\mathrm{MS}$

17. Мордвинов В.А., Поплыпин В.В., Поплыпина И.С. Варианты полимерного заводнения залежи с высоковязкой нефтью // Вестник Пермского национального исследовательского политехнического университета. Геология. Нефтегазовое и горное дело. - 2015. - Т. 14, № 14. - С. 39-51. DOI: $10.15593 / 2224-9923 / 2015.14 .5$

18. Поплыгин В.В., Уирсигроч М. Оценка эффективности применения волнового воздействия в карбонатных коллекторах с высокой вязкостью нефти // Вестник Пермского национального исследовательского политехнического университета. Геология. Нефтегазовое и горное дело. - 2018. - Т. 18, № 2. - С. 149-156. DOI: $10.15593 / 2224-9923 / 2018.4 .5$

19. Гладких Е.А., Хижняк Г.П. Результаты исследований водоизоляционного состава на керновой модели слоисто-неоднородного пласта // Нефтяное хозяйство. - 2017. - № 11. - С. 118-121. DOI: 10.24887/0028-2448-2017-11-118-121

20. О «коварном» законе обводнения и нефтеотдачи карбонатных трещинно-поровых коллекторов / В.И. Колганов, А.А. Фомина, С.В. Демин, А.Ю. Морозова // Нефтяное хозяйство. 2008. - № 1. - С. 66-70.

21. Казаков А.А., Соловьев И.Г. Динамическая модель образования конуса обводнения вертикальной нефтяной скважины // Вестник Тюменского государственного университета. Физико-математическое моделирование. Нефть, газ, энергетика. - 2011. - № 7. - С. 52-58.

22. Азаматов М.А., Шорохов А.Н. Внедрение метода оперативной диагностики источников обводнения нефтяных добывающих скважин // Нефтяное хозяйство. - 2011. - № 12. - С. 63-65.

23. Шувалов С.А., Винокуров В.А., Хлебников В.Н. Применение полимерных реагентов для увеличения нефтеотдачи пласта и водоизоляции // Труды Российского государствен- ного университета нефти и газа им. И.М. Губкина. - 2013. - № 4 (273). - С. 98-107.

24. Избрехт А.В., Паникаровский Е.В., Кустышев А.В. Методы и водоизолирующие композиции для проведения ремонтноизоляционных работ в нефтяных и газовых скважинах // Строительство нефтяных и газовых скважин на суше и на море. -2013 . - № 6. - С. 31-34.

25. Опыт и перспективы применения технологий ограничения водопритока на месторождениях Пермского края / А.В. Распопов, А.С. Казанцев, Д.В. Андреев, И.В. Аверина, Д.Д. Сидоренко, С.Н. Глазырин // Геология, геофизика и разработка нефтяных и газовых месторождений. - 2016. - № 9. - С. 41-45.

26. Куликов А.Н., Силин М.А., Магадова Л.А., Елисеев Д.Ю. Оптимизация последовательности применения технологий ограничения водопритоков и повышения нефтеотдачи пласта в ходе разработки залежей нефти // Территория Нефтегаз. 2013. - № 4. - С. 64-69.

27. Куликов А.Н. Методика выбора скважин для проведения работ по ограничению водопритоков и восстановлению добывающего фонда // Нефтепромысловое дело. - 2012. - № 7 . C. 19-23.

28. Неорганическая гелеобразующая композиция для ограничения водопритока в карбонатных трещиновато-поровых коллекторах / А.М. Кунакова, В.Н. Дурягин, К.В. Стрижнев, Д.В. Мардашов, А.М. Дурягина // Нефтяное хозяйство. - 2015. № 11. - С. 114-116.

29. Батрашкин В.П. Алгоритм выбора скважин для применения комбинированного воздействия со стороны нагнетательной и добывающей скважин на неоднородные нефтенасыщенные коллекторы // Автоматизация, телемеханизация и связь в нефтяной промышленности. - 2007. - № 9. - С. 33-39.

30. Потокоотклоняющие технологии основной метод регулирования разработки высокозаводненных залежей / С.А. Сулима, В.П. Сонич, В.А. Мишарин, В.М. Исаченко, Р.А. Булатов, Д.В. Самсоненко // Нефтяное хозяйство. -2004 . - № 2. - С. 44-50.

31. Мероприятия по ограничению притока пластовых вод и повышению продуктивности скважин / Е.И. Мамчистова, Е.М. Звягин, М. Гусьо, О.В. Валиев, Э.Ф. Коваленко, В.Н. Тапилин // Научный форум. Сибирь. - 2015. - № 1. - С. 53-55.

32. Келлер Ю.А. Разработка искусственных нейронных сетей для предсказания техноло- 
гической эффективности от выравнивания профиля приемистости // Известия Томского политехнического университета. - 2014. - Т. 325, № 5. - C. 60-65.

33. Evaluation of polymer flooding efficiency at brownfield development stage of giant Kalamkas oilfield, western Kazakhstan / M. Sagyndikov, B. Mukhambetov, Y. Orynbasar, A. Nurbulatov, S. Aidarbayev // SPE Annual Caspian Technical Conference and Exhibition. - Astana, 2018. DOI: 10.2118/192555-MS.

34. An injection/production rate allocation method applied for polymer-surfactant flooding / Y. Liu, H. Wu, J. Hou, C. Wei, W. Ren // Journal of Engineering Research. - 5 (2). - P. 250-267.

35. Systematic development and laboratory evaluation of secondary polymer augmentation for a slightly viscous Arabian heavy reservoir / A.M. Al Sofi, J. Wang, A.A. Al Shuaibi, F.A. Al Ghamdi, Z.F. Kaidar // SPE Middle East Oil and Gas Show and Conference, MEOS, Proceedings. - 2017. P. 2757-2764. DOI: 10.2118/183793-MS

36. Waterflooding optimization in case of autofrac naturally fractured reservoir / I.V. Maksimovskiy, A.G. Akimov, A.F. Yamaletdinov, M.A. Zhilina // Society of Petroleum Engineers - SPE Russian Petroleum Technology Conference and Exhibition. 201. - P. 2723-2738. DOI: 10.2118/181991-MS

37. Jin J., Choe J. Positioning of an injection well by combining watercut matching and adjoint method // Proceedings of IAMG 2015 - 17th Annual Conference of the International Association for Mathematical Geosciences. - 2015. - P. 351-356.

38. Guo H.-Z., Li D.-M. Flagship application in high water cut horizontal well // Xinan Shiyou Daxue Xuebao. Journal of Southwest Petroleum University. - 2009. - № 31(1). - C. 107-110. DOI: $10.3863 /$ j.issn.1674-5086.2009.01.026

39. Pu H., Yin D. Study of polymer flooding in class III reservoir and pilot test // Proceedings - SPE Symposium on Improved Oil Recovery. - 2008. № 1. - P. 10-25. DOI: 10.2118/109546-MS
40. Stirpe M.T., Guzman J., Manrique E., Alvarado V. Cyclic water injection simulations for evaluations of its potential in lagocinco field // Proceedings - SPE Symposium on Improved Oil Recovery. - Tulsa, 2004. DOI: 10.2118/89378-MS

41. Thyne G. Evaluation of the effect of low salinity waterflooding for 26 fields in Wyoming // Proceedings - SPE Annual Technical Conference and Exhibition. - 2011. - № 5. - P. 4390-4407. DOI: $10.2118 / 147410-\mathrm{MS}$

42. EOR mechanisms and field practice of flowing gel profiling/flooding / X.-C. Wu, H.-G. Wang, F.-X. Li, Q.-Q. Zeng // Oilfield Chemistry. - 2009. - 26(1). P. 79-83.

43. Галкин С.В., Илюшин П.Ю. Прогноз динамики обводненности скважин в различных геолого-технологических условиях разработки нефтяных месторождений // Нефтяное хозяйство. 2011. - № 10. - C. 22-24.

44. Илюшин П.Ю., Галкин С.В. Прогноз обводненности продукции добывающих скважин Пермского края с применением аналогостатистических методов // Вестник Пермского национального исследовательского политехнического университета. Геология. Нефтегазовое и горное дело. - 2011. - Т. 10, № 1. - С. 76-84.

45. Назарова Л.Н. Обоснование коэффициента извлечения нефти в зависимости от комплекса геолого-физических параметров пластов и насыщающих их флюидов: диссертация на соискание ученой степени доктора технических наук / Российский государственный университет нефти и газа (национальный исследовательский университет) им. И.М. Губкина. - Москва, 2015.

46. Поплыгина И.С. Возможности повышения эффективности разработки залежи с высоковяз-кой нефтью на территории Пермского края // Вестник Пермского национального исследо-вательского политехнического университета. Геология. Нефтегазовое и горное дело. - 2014. - Т. 13, № 11. C. 57-66. DOI: 10.15593/2224-9923/2014.11.6

Please cite this article in English as:

Poplygina I.S., Wiercigroch M. Express predicting movement of displacement front to high viscosity oil reservoirs. Perm Journal of Petroleum and Mining Engineering, 2019, vol.19, no.2, pp.175-183. DOI: 10.15593/2224-9923/2019.2.7

Просьба ссылаться на эту статью в русскоязычных источниках следующим образом:

Поплыгина И.С., Уирсигроч М. Экспресс-прогнозирование перемещения фронта вытеснения на залежи с высоковязкой нефтью // Вестник Пермского национального исследовательского политехнического университета. Геология. Нефтегазовое и горное дело. - 2019. - Т.19, №2. - C.175-183. DOI: 10.15593/2224-9923/2019.2.7 